\title{
STRUCTURE AND PROPERTIES OF Fe-B-C POWDERS ALLOYED WITH Cr, V, Mo OR Nb FOR PLASMA-SPRAYED COATINGS
}

\author{
O.V. Sukhova \\ The Oles' Honchar Dnipro National University, \\ Dnipro, Ukraine \\ E-mail: sukhovaya@ukr.net
}

In the present study, the microstructure development and properties of the starting Fe-B-C powders for plasma spraying fabricated by dispersing a consumable rotating rod were investigated as functions of alloying elements additions. These powders were prepared in the following compositional ranges: B (10...14 wt.\%), $\mathrm{C}(0.01 \ldots 0.5$ wt.\%), Me (0..5.0 wt.\%), where $\mathrm{Me}-\mathrm{Cr}, \mathrm{V}$, Mo or $\mathrm{Nb}$, balance Fe. Structural properties were characterized by metallography, X-ray diffraction, scanning electron microscopy, and energy dispersive spectroscopy. Mechanical properties of the powders were measured by a Vickers indenter. Compression strength, oxidation resistance, and melting temperature were also determined. Chromium or vanadium were found to dissolve completely in $\mathrm{Fe}_{2}(\mathrm{~B}, \mathrm{C})$ and $\mathrm{Fe}(\mathrm{B}, \mathrm{C})$ constituent phases of the $\mathrm{Fe}-\mathrm{B}-\mathrm{C}$ powders replacing iron and forming substitutional solid solutions. By entering into the iron borides structure, these alloying elements improve ductility and oxidation resistance but lower melting temperature and hardness of the powders. Molybdenum or niobium were mainly found in secondary phases such as $\mathrm{Mo}_{2} \mathrm{~B}, \mathrm{Mo}_{2}(\mathrm{~B}, \mathrm{C})$ or $\mathrm{NbB}_{2}$ at the $\mathrm{Fe}_{2}(\mathrm{~B}, \mathrm{C})$ boundaries. As a result, these alloying elements enhance hardness, oxidation resistance and melting temperature of the powders.

PACS: 81.10.Fq, 81.30t, 61.50 Ks, 52 .50 Dg, 52.77. Dq, 61.66.Dk, 64.70.Kb

\section{INTRODUCTION}

Boron-rich Fe-B-C alloys with boron content in the range of $10 \ldots 14 \mathrm{wt} . \%$ are nowadays well-established materials due to their high hardness, relatively low coefficient of friction, and good oxidation and corrosion resistance [1-4]. As such these alloys have attracted significant attention both in basic as well as in applied research areas, resulting in several studies on phase stability, mechanical and performance properties of the ternary Fe-B-C system [5-7]. These properties are attributed to the formation of $\mathrm{Fe}_{2} \mathrm{~B}$ and $\mathrm{FeB}$ borides in the structure which are major constituents of boron-rich Fe-B alloys. Meanwhile, carbon may be considered as natural addition to Fe-B alloys since these alloys are very reactive with respect to carbon. This element is found to dissolve in the iron borides forming $\mathrm{Fe}(\mathrm{B}, \mathrm{C})$ and $\mathrm{Fe}_{2}(\mathrm{~B}, \mathrm{C})$ solid solutions and add strength at elevated temperatures [8]. At that, with cooling rate of Fe-B-C alloys increasing, carbon solubility increases which enhances solid-solution strength, as well as hardness.

In view of the increasing importance of boron-rich Fe-B-C alloys in practical applications, it is surprising how little is known about the influence of alloying elements on their structure and properties. The studies mainly concern the effects of alloying on boroncontaining steels [9-14]. Very important elements for alloy steels are chromium, vanadium, molybdenum, and niobium. Probably one of the most well-known effects of chromium on steel is the tendency to resist staining and corrosion. Chromium can also increase the toughness of steel, as well as the wear resistance. The metal also improves hardenability, strength, response to heat treatment. Vanadium can produce stable carbides that increase strength at high temperatures. By inhibiting grain growth during heat treatment, it helps enhance the toughness and strength of the steel. Molybdenum tends to minimize temper brittleness and protects against pitting corrosion caused by chlorides and sulfur chemicals. Found in small quantities in stainless steels, molybdenum increases hardenability and strength at high temperatures. Niobium like vanadium has the benefit of stabilizing carbon by forming hard carbides and, so, is often found in high temperature steels. In small amounts, niobium can significantly increase the yield strength and, to a lesser degree, the tensile strength of steels, as well as have a moderate precipitation strengthening effect.

Fe-B-C alloys are widely used as protective hard coatings produced by various methods, including plasma spray of atomized powders [15-19]. Plasma spraying process that utilizes a high energy heat source to melt and to accelerate fine powders onto a prepared surface is very effective for producing thick coatings due to their rapid cooling rates. Fe-B-C plasma-sprayed coatings have attracted interest due to their unique mechanical properties, high wear resistance, excellent corrosion resistance, and low cost [20-22]. The main advantages of using plasma spraying to form Fe-B-C coatings include good adhesion between the coating and substrate and reproducible results. In addition, plasma spraying is an industrial process, enabling mass production.

Performance properties of plasma-sprayed coatings are strongly influenced by a structure of starting powders [23, 24]. Alloying is a powerful method to improve the characteristics of powders for the manufacture of coatings. Understanding both the positive and negative effects of alloying elements on the structure and properties of boron-rich Fe-B-C powders can help to identify what applications certain coatings can be used in. The very high cooling rates of atomization processes may also contribute to the solubility of alloying elements in phase constituents of the powders thus affecting their properties.

Therefore, the purpose of this work is to investigate the influence of alloying elements $(\mathrm{Cr}, \mathrm{V}, \mathrm{Mo}$ or $\mathrm{Nb}$ ) on the formation of structure and properties of boron-rich Fe-B-C powders for plasma straying. 


\section{MATERIALS AND METHODS}

Fe-B-C-Me powders for plasma spraying containing $10.0 \ldots 14.0 \% \mathrm{~B}, 0.01 \ldots 0.5 \% \mathrm{C}, 0 \ldots 5.0 \% \mathrm{Me}$ (where $\mathrm{Me}-\mathrm{Cr}, \mathrm{V}$, Mo or $\mathrm{Nb}$ ), balance Fe (in wt.\%) (purity better than $98.5 \%$ ) were produced by dispersing a consumable rotating rod $[25,26]$. A rotating rod (anode), which was $28 \ldots 30 \mathrm{~mm}$ in diameter and $200 \ldots 300 \mathrm{~mm}$ in length, made of the alloy to be atomized, was melted by an electric arc between the anode and a water-cooled tungsten cathode. Liquid powders were then projected from the anode by the centrifugal force and solidified in the chamber filled with argon at a pressure of $0.1 \ldots 0.15 \mathrm{MPa}$. The atomization process parameters were as follows: $380 \ldots 400 \mathrm{~A}, 40 \mathrm{~V}$. The lower threshold was determined by the requirement of the highest output of the process. But, if the strength of current was higher than $400 \mathrm{~A}$, there was not enough time for metal to spheroidize and it solidified as shapeless powders. But the powders to be injected into the plasma must possess good flow properties, which is associated with their spherical shape. The powders diameters ranged from 100 to $200 \mu \mathrm{m}$, and average diameter defined by the cumulative weight fraction of $50 \%$ was about $125 \mu \mathrm{m}$. Powders with this narrow size distribution are preferred in order to achieve uniform heating and acceleration of a multicomponent powder. The cooling rate of the powders was $10^{3} \ldots 10^{4} \mathrm{~K} / \mathrm{s}$.

The microstructural characterization of the powders was performed by light metallographic microscope Neophot-32 and quantitative analyzer Epiquant. The Xray diffraction (XRD) measurements of lattice parameters of the phases were carried out using diffractometer HZG-4A with $\mathrm{CuK}_{\alpha}$ radiation. The XRD analyses were performed with powder samples. The microstructure was also studied with a scanning electron microscope Jeol-2010 F (SEM) equipped with an energy dispersive spectrometer (EDS). The melting temperature $\left(T_{\mathrm{m}}\right)$ of the powders was measured by differential thermal analysis at $5 \mathrm{~K} / \mathrm{min}$ heating rate.

Vickers microhardness tests were carried out using device PMT-3 at $0.05 \mathrm{~kg}$ load in order to observe the crack propagation in the samples. A mean Vickers microhardness $\left(H_{\mu}\right)$ was obtained by averaging over 20 indentations. Total Vickers hardness was calculated considering additivity of this characteristic. The fracture toughness $\left(K_{\mathrm{IC}}\right)$ was evaluated from the crack length initiated at the corners of the Vickers microindentation using an empirical equation proposed in [27]. Compression strength $(\sigma)$ was measured at room temperature with load applied up to fracture of the powders. Oxidation resistance factor $\left(K_{\mathrm{o}}\right)$ was measured with powders oxidized in air at $1273 \mathrm{~K}$ for $2 \mathrm{~h}$.

\section{RESULTS AND DISCUSSION}

The effects of alloying elements in boron-rich Fe-B-C powders are as follows. The addition to powders of elements such as $\mathrm{Cr}$ or $\mathrm{V}$ does not basically alter the microstructures formed. The $\mathrm{Fe}_{2} \mathrm{~B}$ - and $\mathrm{FeB}$ based solid solutions are observed in the structure (Figs. $1,2)$. So, the chromium or vanadium do not form chemical compounds, and consequently the only form in which they can be present in the powders is in solid solutions with iron borides. Chromium and vanadium can dissolve in either the $\mathrm{Fe}_{2} \mathrm{~B}$ and $\mathrm{FeB}$ borides but predominantly they dissolve into iron monoboride (see Figs. 1, 2). These elements tend to cause distortions of crystal lattices of $\mathrm{Fe}_{2}(\mathrm{~B}, \mathrm{C})$ and $\mathrm{Fe}(\mathrm{B}, \mathrm{C})$ typical for substitutional solid solutions. Their atoms are of similar size and behaviour [28] and so the lattice structure of the $\mathrm{Fe}_{2} \mathrm{~B}$ and $\mathrm{FeB}$ borides does not alter greatly as a result of substituting $\mathrm{Fe}$ atoms for $\mathrm{Cr}$ or $\mathrm{V}$ (Table 1).

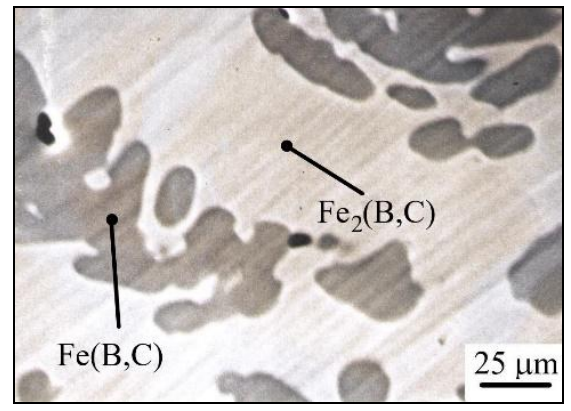

$a$

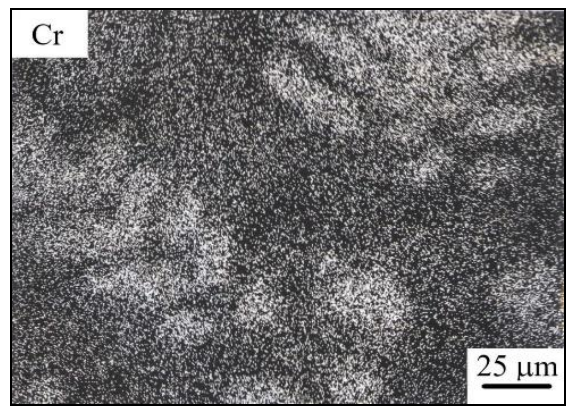

$b$

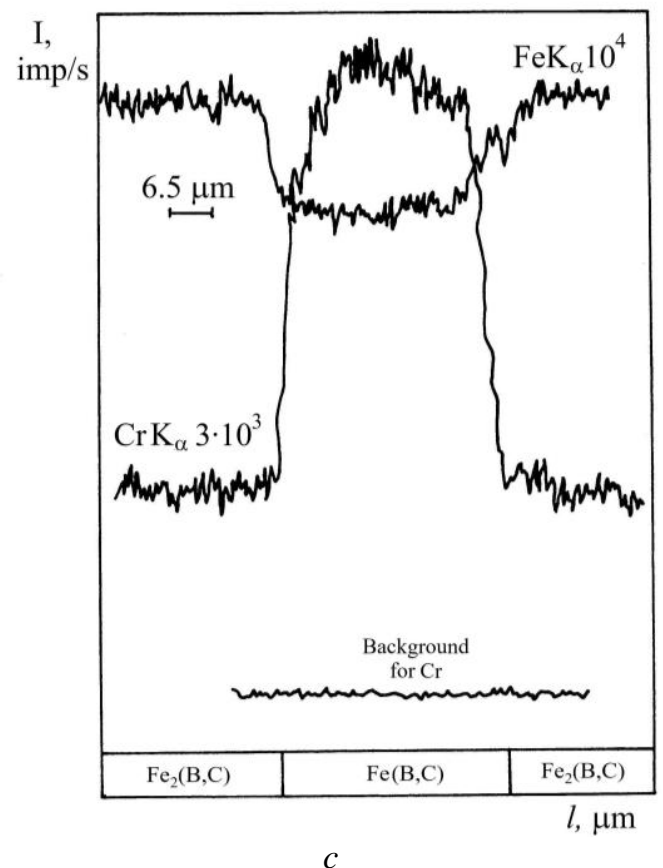

Fig. 1. SEM of polished cross-sections of Fe-12.1B-0.1C powder alloyed with $5 \%$ of $\mathrm{Cr}$ : a-second electron image; $b$-elemental EDS X-ray mapping; $c$-elemental profile along scanning line 
The lattice parameters of $\mathrm{Fe}(\mathrm{B}, \mathrm{C})$ and $\mathrm{Fe}_{2}(\mathrm{~B}, \mathrm{C})$ crystals in the $\mathrm{Fe}-12.1 \mathrm{~B}-0.1 \mathrm{C}$ powders alloyed with $5 \%$ of $\mathrm{V}, \mathrm{Cr}$, Mo or $\mathrm{Nb}$

\begin{tabular}{|c|c|c|c|c|c|c|}
\hline \multirow{2}{*}{$\begin{array}{c}\text { Alloying } \\
\text { element }\end{array}$} & \multicolumn{3}{|c|}{$\mathrm{Fe}(\mathrm{B}, \mathrm{C})$ (rhombic lattice) } & \multicolumn{2}{c|}{$\mathrm{Fe}_{2}(\mathrm{~B}, \mathrm{C})$ (tetragonal lattice) } \\
\cline { 2 - 7 } & $a, \AA$ & $b, \AA$ & $c, \AA$ & $a, \AA$ & $c, \AA$ & $c / a$ \\
\hline $\mathrm{w} / \mathrm{o}$ & $5.5041 \pm 0.0052$ & $4.0596 \pm 0.0106$ & $2.9501 \pm 0.0037$ & $5.1120 \pm 0.0001$ & $4.2418 \pm 0.0001$ & 0.8298 \\
\hline $\mathrm{Cr}$ & $5.4911 \pm 0.0032$ & $4.0569 \pm 0.0052$ & $2.9602 \pm 0.0021$ & $5.1173 \pm 0.0004$ & $4.2313 \pm 0.0046$ & 0.8269 \\
\hline $\mathrm{V}$ & $5.4998 \pm 0.0020$ & $4.0576 \pm 0.0066$ & $2.9697 \pm 0.0011$ & $5.1174 \pm 0.0014$ & $4.2427 \pm 0.0053$ & 0.8291 \\
\hline $\mathrm{Mo}$ & $5.5083 \pm 0.0018$ & $4.0671 \pm 0.0038$ & $2.9663 \pm 0.0007$ & $5.1184 \pm 0.0010$ & $4.2467 \pm 0.0075$ & 0.8297 \\
\hline $\mathrm{Nb}$ & $5.5055 \pm 0.0042$ & $4.0688 \pm 0.0067$ & $2.9491 \pm 0.0042$ & $5.1131 \pm 0.005$ & $4.2414 \pm 0.0028$ & 0.8295 \\
\hline
\end{tabular}
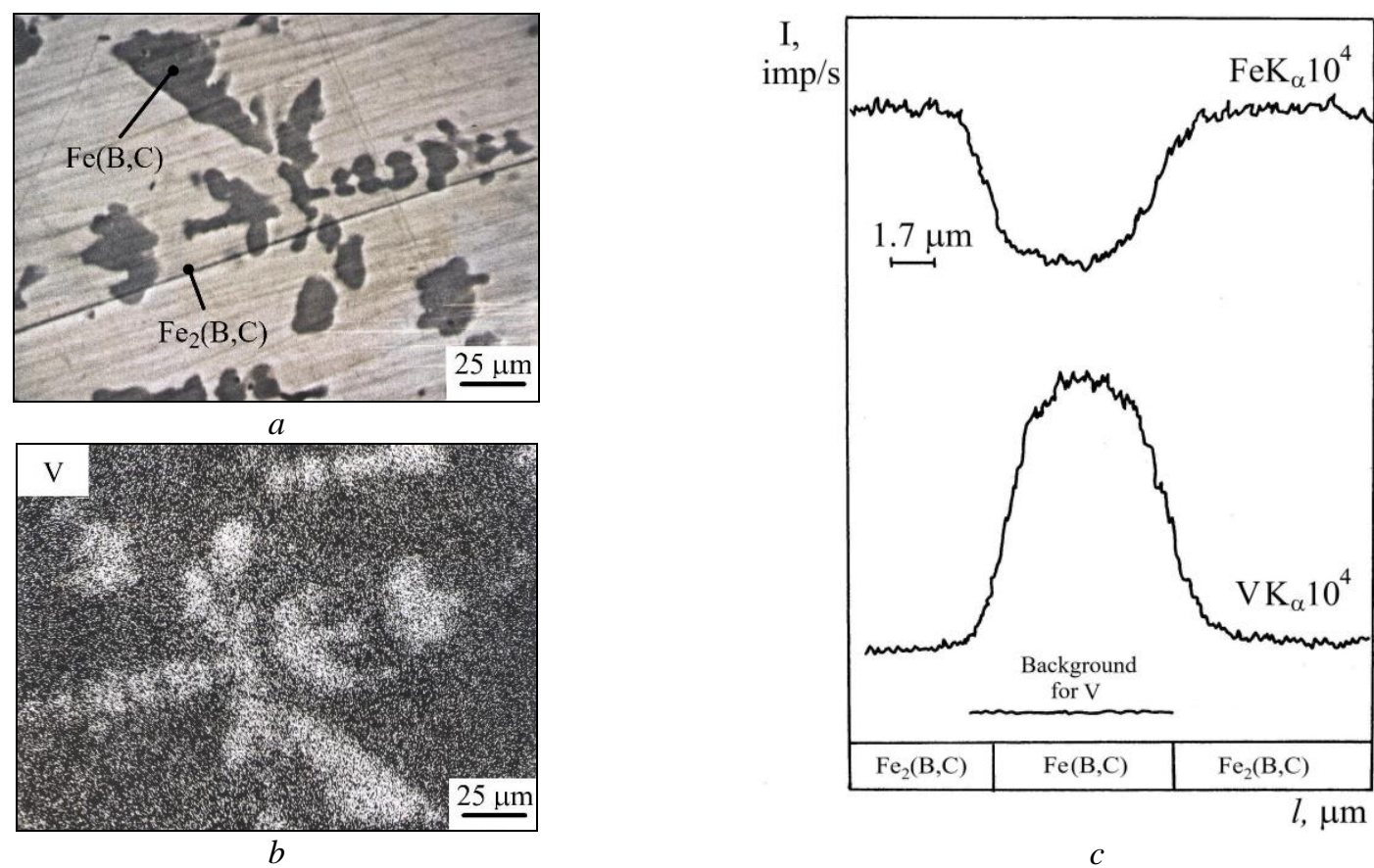

Fig. 2. SEM of polished cross-sections of Fe-12.1B-0.1C powder alloyed with $5 \%$ of $\mathrm{V}$ :

$a$-second electron image; $b$-elemental EDS X-ray mapping; $c$-elemental profile along scanning line

Table 2

Structural and mechanical characteristics of $\mathrm{Fe}(\mathrm{B}, \mathrm{C})$ and $\mathrm{Fe}_{2}(\mathrm{~B}, \mathrm{C})$ crystals in the $\mathrm{Fe}-12.1 \mathrm{~B}-0.1 \mathrm{C}$ powders alloyed with $5 \%$ of $\mathrm{V}, \mathrm{Cr}$, Mo or $\mathrm{Nb}$

\begin{tabular}{|c|c|c|c|c|c|c|c|}
\hline \multirow{2}{*}{$\begin{array}{c}\text { Alloying } \\
\text { element }\end{array}$} & \multicolumn{3}{|c|}{$\mathrm{Fe}(\mathrm{B}, \mathrm{C})$} & \multicolumn{2}{c|}{$\mathrm{Fe}_{2}(\mathrm{~B}, \mathrm{C})$} \\
\cline { 2 - 5 } & \multicolumn{3}{|c|}{ Dendrite parameters*, $H_{\mu}, \mathrm{GPa}$} & \multirow{2}{*}{$K_{\mathrm{IC}}, \mathrm{MPa} \cdot \mathrm{m}^{1 / 2}$} & \multirow{2}{*}{$H_{\mu}, \mathrm{GPa}$} & \multirow{2}{*}{$K_{\mathrm{IC}}, \mathrm{MPa} \cdot \mathrm{m}^{1 / 2}$} \\
\cline { 2 - 8 } & $d_{0}$ & $l_{0}$ & $d_{0} / l_{0}$ & & & \\
\hline $\mathrm{w} / \mathrm{o}$ & $4.9 \pm 0.1$ & $5.3 \pm 0.1$ & 0.92 & $20.1 \pm 0.1$ & $5.0 \pm 0.2$ & $17.0 \pm 0.1$ & $4.5 \pm 0.1$ \\
\hline $\mathrm{Cr}$ & $4.1 \pm 0.1$ & $4.3 \pm 0.1$ & 0.95 & $18.6 \pm 0.2$ & - & $15.7 \pm 0.3$ & $5.2 \pm 0.1$ \\
\hline $\mathrm{V}$ & $4.4 \pm 0.1$ & $4.8 \pm 0.1$ & 0.92 & $19.1 \pm 0.1$ & - & $15.8 \pm 0.2$ & - \\
\hline $\mathrm{Mo}$ & $3.1 \pm 0.1$ & $3.6 \pm 0.1$ & 0.86 & $21.0 \pm 0.2$ & $4.4 \pm 0.1$ & $17.8 \pm 0.2$ & $4.1 \pm 0.1$ \\
\hline $\mathrm{Nb}$ & $2.4 \pm 0.05$ & $2.8 \pm 0.1$ & 0.86 & $20.2 \pm 0.1$ & $4.9 \pm 0.1$ & $17.1 \pm 0.1$ & $4.4 \pm 0.2$ \\
\hline
\end{tabular}

$*$ Where $d_{0}$ - diameter of secondary dendritic arms, $l_{0}$ - interdendritic distance.

In the Fe-B-C powders, the presence of chromium or vanadium increases fracture toughness $K_{\mathrm{IC}}$ while not appreciably reducing Vickers hardness $H_{\mu}$ of the constituent phases (Table 2). Chromium or vanadium improve significantly compression strength $\sigma$ and oxidation resistance factor $K_{\mathrm{o}}$ due to formation of inert passive films on the surface which resist attack by oxidizing reagents (Table 3 ). In Fe-B-C powders, chromium appears to have a greater beneficial effect on compression strength but vanadium - on resistance to oxidation. These elements also provide slightly lower melting temperature $T_{\mathrm{m}}$.
Table 3

Performance properties of Fe-10.3B-0.7C-5.0 Me powders $(\mathrm{Me}-\mathrm{Cr}, \mathrm{V}$, Mo or $\mathrm{Nb})$

\begin{tabular}{|c|c|c|c|c|}
\hline $\begin{array}{c}\text { Alloying } \\
\text { element }\end{array}$ & $\begin{array}{c}\text { Total } H_{\mu}, \\
\mathrm{GPa}\end{array}$ & $\sigma, \mathrm{MPa}$ & $T_{\mathrm{m}}, \mathrm{K}$ & $\begin{array}{c}K_{\mathrm{o}}, \text { relative } \\
\text { units }\end{array}$ \\
\hline $\mathrm{w} / \mathrm{o}$ & $17.9 \pm 0.1$ & $2610 \pm 10$ & $1723 \pm 4$ & 1.0 \\
\hline $\mathrm{Cr}$ & $16.6 \pm 0.2$ & $2850 \pm 20$ & $1713 \pm 4$ & $1.32 \pm 0.12$ \\
\hline $\mathrm{V}$ & $16.8 \pm 0.1$ & $2800 \pm 20$ & $1713 \pm 4$ & $1.53 \pm 0.08$ \\
\hline $\mathrm{Mo}$ & $19.1 \pm 0.2$ & $2750 \pm 10$ & $1758 \pm 4$ & $1.12 \pm 0.10$ \\
\hline $\mathrm{Nb}$ & $18.8 \pm 0.1$ & $2675 \pm 20$ & $1763 \pm 4$ & $1.24 \pm 0.06$ \\
\hline
\end{tabular}


Small amounts of Mo added to Fe-B-C powders completely dissolve. At some point, additional amounts of this alloying element will not dissolve. When that solid solubility limit is exceeded, Mo slightly dissolves in $\mathrm{Fe}_{2} \mathrm{~B}$ boride but preferentially in FeB dendrites refining their size (Fig. 3, Table 2). The addition of this element that dissolves in the $\mathrm{Fe}_{2} \mathrm{~B}$ and $\mathrm{FeB}$ lattices replacing iron atoms causes noticeable distortions because of the difference in atom size (see Table 1) [28]. Besides, with boron molybdenum forms $\mathrm{Mo}_{2} \mathrm{~B}$, but in the presence of carbon it forms $\mathrm{Mo}_{2}(\mathrm{~B}, \mathrm{C})$ as well. Thus, at the amount of 5\% this alloying element forms mainly special borides and borocarbides.
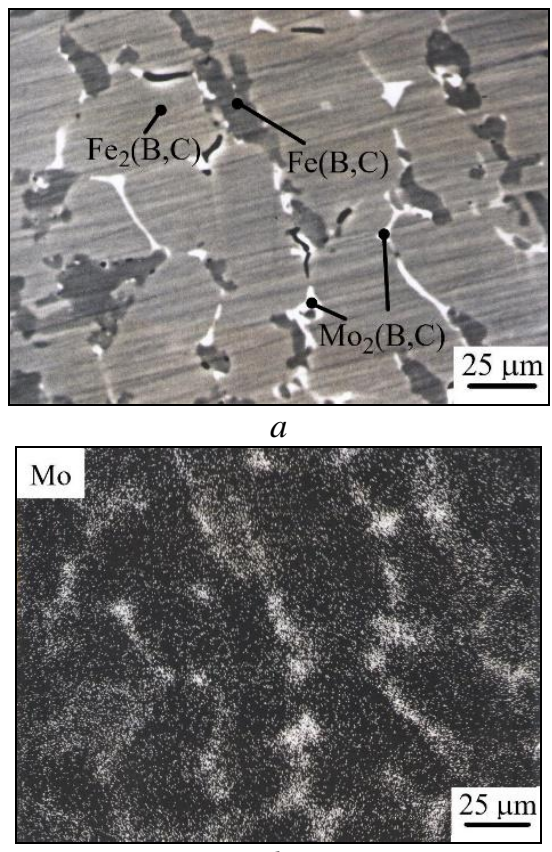

$b$

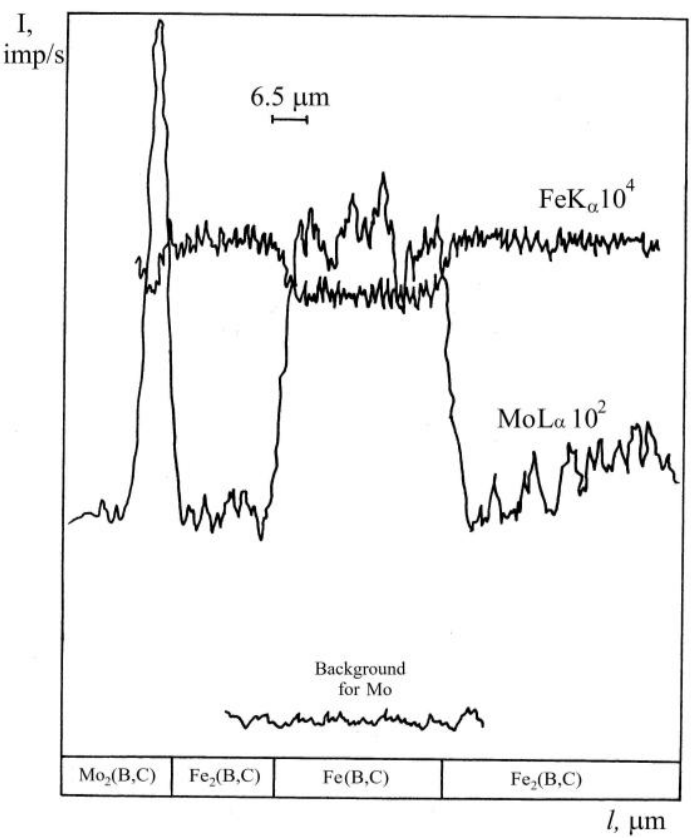

$C$

Fig. 3. SEM of polished cross-sections of Fe-12.1B-0.1C powders alloyed with 5\% of Mo: a-second electron image; $b$-elemental EDS X-ray mapping; $c$-elemental profile along scanning line
Since the molybdenum atoms are larger than the surrounding atoms, they introduce compressive lattice strains. They disrupt the regular arrangement of ions and make it more difficult for the layers to slide over each other. This makes the $\mathrm{FeB}$ and $\mathrm{Fe}_{2} \mathrm{~B}$ phases harder and less ductile than those of the master $\mathrm{Fe}-\mathrm{B}-\mathrm{C}$ powders (see Table 2). For example, powders of 5\% Mo raise the total hardness from 17.9 to $19.1 \mathrm{GPa}$ (see Table 3). Besides, the addition of Mo to Fe-B-C powders rises melting temperature and slightly improves oxidation resistance.

When niobium is added to Fe-B-C powders, it does not form solutions in iron borides and enters $\mathrm{NbB}_{2}$ secondary phase formed at $\mathrm{Fe}_{2}(\mathrm{~B}, \mathrm{C})$ boundaries (Fig. 4).
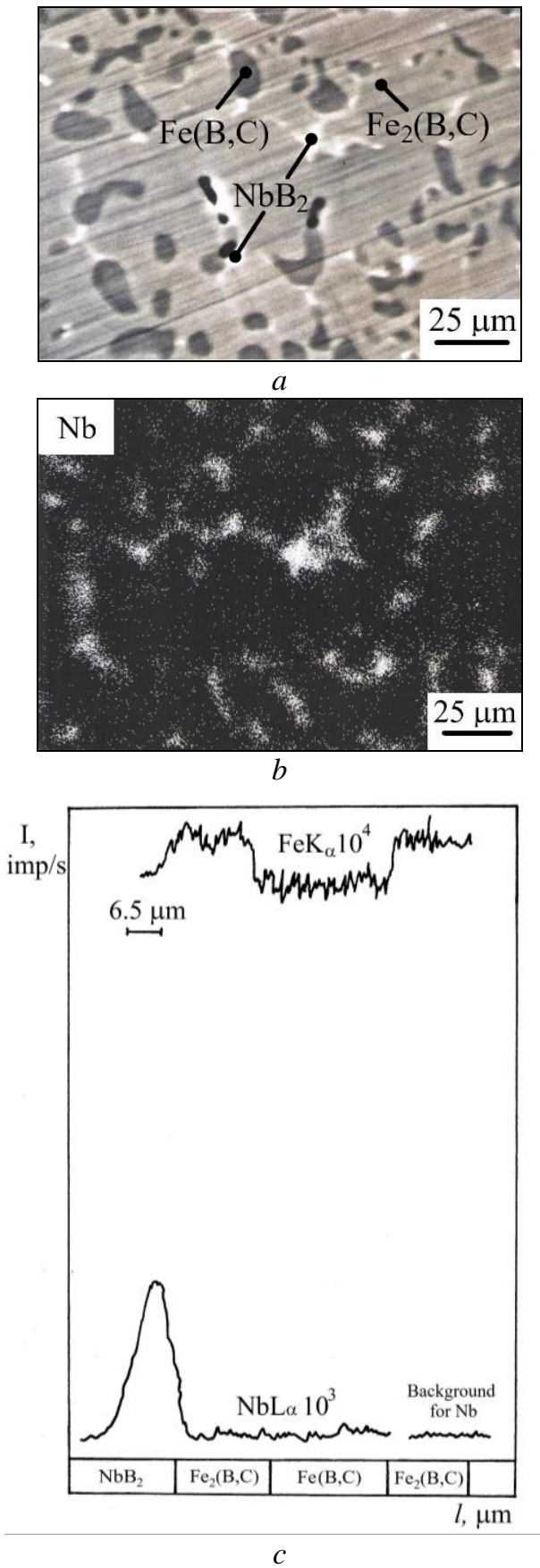

Fig. 4. SEM of polished cross-sections of Fe-12.1B-0.1C powders alloyed with $5 \%$ of $\mathrm{Nb}:$ a-second electron image; $b$-elemental EDS $X$-ray mapping; $c$-elemental profile along scanning line 
Insolubility of niobium in iron borides is in good agreement with XRD measurements of lattice parameters of $\mathrm{Fe}(\mathrm{B}, \mathrm{C})$ and $\mathrm{Fe}_{2}(\mathrm{~B}, \mathrm{C})$ phases (see Table 1). This implies that $\mathrm{Nb}$ is continually pushed out in the melt ahead of the moving solid-liquid interface into the interdendritic regions of growing $\mathrm{Fe}(\mathrm{B}, \mathrm{C})$ dendrites slowing their growth and causing noticeable refinement (see Table 2). As a result, the secondary crystals of $\mathrm{NbB}_{2}$ appear at the $\mathrm{Fe}_{2}(\mathrm{~B}, \mathrm{C})$ boundaries.

$\mathrm{Fe}-\mathrm{B}-\mathrm{C}$ powders with $5 \%$ niobium are harder (see Table 3), on account of the finer $\mathrm{Fe}(\mathrm{B}, \mathrm{C})$ dendrites formed and the presence of $\mathrm{NbB}_{2}$ secondary phase. Niobium, as such, performs in the same way as that described for molybdenum. The addition of niobium to Fe-B-C powders has a substantial effect on the melting temperature (see Table 3). Its presence also improves oxidation at high temperatures.

It should be noted that the solubility of investigated alloying elements in the constituent phases of Fe-B-C powders increases in the order $\mathrm{Nb}, \mathrm{Mo}, \mathrm{V}, \mathrm{Cr}$. Taking into account the metallic radii of individual metal atoms [28] allows to explain why $\mathrm{Cr}$ and $\mathrm{V}$ completely dissolve in $\mathrm{Fe}-\mathrm{B}-\mathrm{C}$ powders, but $\mathrm{Mo}$ and $\mathrm{Nb}$ have partial or no solubility, as in this sequence the atomic radii decrease. It is also understandable why alloying elements are predominantly dissolved in the rhombic lattice of $\mathrm{Fe}(\mathrm{B}, \mathrm{C})$ than in more close-packed tetragonal lattice of $\mathrm{Fe}_{2}(\mathrm{~B}, \mathrm{C})$.

For a thorough understanding of mechanical properties of alloyed Fe-B-C powders, it is important to consider the electronic structure of the constituent phases, including the electron distribution [29]. In $\mathrm{Fe}_{2}(\mathrm{~B}, \mathrm{C})$, boron forms strong covalent $\mathrm{Fe}-\mathrm{B}$ bonds [30]. According to the crystal structure, these bonds connect $\mathrm{B}$ to eight neighboring $\mathrm{Fe}$ atoms. In the crystal structure of $\mathrm{Fe}(\mathrm{B}, \mathrm{C}), \mathrm{B}$ atoms forming zigzag chains are in the interstices surrounded by $\mathrm{Fe}$ atoms. The strong interactions between the atoms lead to strong covalent B-B bonds. The combination of the covalent $\mathrm{Fe}-\mathrm{B}$ bonds and metallic $\mathrm{Fe}-\mathrm{Fe}$ bonds in $\mathrm{Fe}_{2}(\mathrm{~B}, \mathrm{C})$ or the combination of the covalent $\mathrm{B}-\mathrm{B}$ bonds and metallic $\mathrm{Fe}-\mathrm{Fe}$ bonds in $\mathrm{Fe}(\mathrm{B}, \mathrm{C})$ contribute to the properties of these compounds [30].

In assessing the alloying effects, the relative change in concentration of the collectivized valence electrons forming the $\mathrm{Fe}-\mathrm{B}$ and $\mathrm{Fe}-\mathrm{Fe}$ bonds, when $\mathrm{Fe}$ atoms are replaced by $\mathrm{Me}$ atoms (where $\mathrm{Me}-\mathrm{Cr}, \mathrm{V}$ or $\mathrm{Mo}$ ), is responsible for the observed changes in mechanical properties. Here, a decrease in hardness is predicted by alloying with $\mathrm{Cr}$ and $\mathrm{V}$, related to a decreased concentration of collectivized electrons taking part in the electronic exchange [29]. As a result, Me-B and Fe$\mathrm{Me}$ bonds become weaker; the hardness of the Fe-B-C powders is found to reduce, but compression strength improves.

According to electronic structure of $\mathrm{Mo}$ and $\mathrm{Nb}$, these elements rather act as electron acceptors. Their valence electrons are localized in the stable $d^{5}$ configurations [29]. Any re-distribution of bonding electrons caused by replacing $\mathrm{Fe}$ with $\mathrm{Mo}$ or $\mathrm{Nb}$ in the crystal lattices of $\mathrm{Fe}(\mathrm{B}, \mathrm{C})$ and $\mathrm{Fe}_{2}(\mathrm{~B}, \mathrm{C})$ phases leads to destruction of stable configurations. It results in limited or extremely low solubility of correspondingly Mo or
$\mathrm{Nb}$ and formation of secondary phases. In the Fe-B-C powders, some of the added molybdenum ions, larger than iron ions making up the lattice, disrupt the regular arrangement of ions and make it more difficult for the layers to slide over each other. This makes the powders harder and less ductile than the master powder (in which the layers slip over each other more easily). Niobium does not contribute to any hardness increase of $\mathrm{Fe}(\mathrm{B}, \mathrm{C})$ and $\mathrm{Fe}_{2}(\mathrm{~B}, \mathrm{C})$ phases and enhances the hardness of powders with preserving compression strength by strengthening via the precipitation of secondary phases.

\section{CONCLUSIONS}

This study shows that the major constituents of boron-rich Fe-B-C powders sized from 100 to $200 \mu \mathrm{m}$ in diameter are found to be $\mathrm{Fe}(\mathrm{B}, \mathrm{C})$ and $\mathrm{Fe}_{2}(\mathrm{~B}, \mathrm{C})$ solid solutions. When adding up to $5 \%$ of $\mathrm{Cr}$ or $\mathrm{V}$ to $\mathrm{Fe}-\mathrm{B}-\mathrm{C}$ powders, these elements have complete solubility in the structural constituents, preferentially dissolving in $\mathrm{Fe}(\mathrm{B}, \mathrm{C})$ phase and forming substitutional solutions. $\mathrm{Cr}$ or $\mathrm{V}$ introduce the smallest lattice distortions which relates to the relatively small differences in the atomic sizes between the iron and substituting atoms.

Molybdenum or niobium have correspondingly a limited or extremely low solubility in Fe-B-C powders. At that, the refinement of structure is observed by Mo or $\mathrm{Nb}$ additions. When the Mo or $\mathrm{Nb}$ content reaches 5\%, these elements are found in powders in the form of chemical compounds with boron and/or carbon $\left(\mathrm{Mo}_{2} \mathrm{~B}\right.$, $\left.\mathrm{Mo}_{2}(\mathrm{~B}, \mathrm{C}), \mathrm{NbB}_{2}\right)$ precipitated at $\mathrm{Fe}_{2}(\mathrm{~B}, \mathrm{C})$ boundaries.

All alloying elements that form solid solutions in $\mathrm{Fe}(\mathrm{B}, \mathrm{C})$ and $\mathrm{Fe}_{2}(\mathrm{~B}, \mathrm{C})$ phases affect their hardness. Chromium, similar to vanadium, decreases hardness, while molybdenum gives the hardness increase caused by substitutional strengthening. This is because the different atom size of Mo interrupts the orderly arrangement of atoms in the lattices. Besides, molybdenum like niobium increases hardness due to formation of secondary phases.

Chromium has the largest effect on compression strength, followed by decreasing effects from vanadium, molybdenum and then niobium. Although different mechanisms are involved in compression strength, the addition of all alloying elements produces a rise in this characteristic.

Chromium or vanadium are most effective for improving oxidation resistance whereas molybdenum or niobium increases this property to a lesser degree. This improvement of the oxidation resistance is credited to the affinity of alloying elements for oxygen and, as a consequence, protective films are formed on the surface of the powders that prevent the further diffusion of oxygen.

Alloying elements, such as $\mathrm{Cr}$ and $\mathrm{V}$, which enter into $\mathrm{Fe}(\mathrm{B}, \mathrm{C})$ and $\mathrm{Fe}_{2}(\mathrm{~B}, \mathrm{C})$ solid solutions lower the melting temperature, with the exception of $\mathrm{Mo}$ and $\mathrm{Nb}$ that give rise to melting temperature.

The effects of investigated alloying elements replacing iron atoms in the $\mathrm{Fe}-\mathrm{B}-\mathrm{C}$ powders may be explained considering a local change of the electronic structure of alloyed $\mathrm{Fe}(\mathrm{B}, \mathrm{C})$ and $\mathrm{Fe}_{2}(\mathrm{~B}, \mathrm{C})$ phases which is an indicator for stronger/weaker bonded atoms in the crystals. 


\section{REFERENCES}

1. Z.F. Huang, J.D. Xing, S.Q. Ma, Y.M. Gao, M. Zheng, L.Q. Sun. Microstructure and properties of Fe-B-C cast wear-resistant alloy // Key Engineering Materials. 2017, v. 732, p. 59-68.

2. X. Ren, H. Fu, J. Xing, Y. Yang, S. Tang. Effect of boron concentration on microstructures and properties of Fe-B-C alloy steel // Journal of Materials Research. 2017, v. 32(16), p. 304-314.

3. P. Sang, H. Fu, Y. Qu, C. Wang, Y. Lei. Effect of boron concentration on solidification structure and hardness of Fe-B-C wear-resistant alloy // Materialwissenschaft und Werkstofftechnik. 2015, v. 46(9), p. 962-969.

4. A.P. Vashchenko, I.M. Spiridonova, E.V. Sukhovaya. Deformation and fracture of structural materials under high-rate strain // Metallurgia. 2000, v. 39(2), p. 89-92 (in Russian).

5. A. Sudo, T. Nishi, N. Shirasu, M. Takano, M. Kurata. Fundamental experiments on phase stabilities of Fe-B-C ternary systems // Journal of Nuclear Science and Technology. 2015, v. 52(10), p. 1308-1312.

6. I.M. Spiridonova, E.V. Sukhovaya, V.P. Balakin. Structure and deformation peculiarities of $\mathrm{Fe}(\mathrm{B}, \mathrm{C})$ crystals // Metallurgia. 1996, v. 35(2), p. 65-68 (in Russian).

7. V. Homolova, L. Ciripova, A. Vyrostkova. Experimental study of phase composition of $\mathrm{Fe}$ (30...60)B-C alloys and boron-rich corner of Fe-B-C phase diagram//Journal of Phase Equilibria and Diffusion. 2015, v. 36(6), p. 599-605.

8. O.V. Sukhova. The effect of carbon content and cooling rate on the structure of boron-rich Fe-B-C alloys // Physics and Chemistry of Solid State. 2020, v. 21(2), p. 355-360.

9. L. Sidney. Alloy Steel: Property and Use. Wilmington: "Scitus Academics LLC", 2016, 302 p.

10. V.G. Efremenko, K. Shimizu, T.V. Pastukhova, Yu.G. Chabak, M.N. Brykov, K. Kusumoto, A.V. Efremenko. Three-body abrasive wear behaviour of metastable spheroidal carbide cast irons with different chromium contents // International Journal of Materials Research. 2018, v. 109(2), p. 147-156.

11. W. Elghazaly, R. Rashad, S. Elmohr, S. Elghazaly. Influence of vanadium and boron additions on the microstructure, fracture toughness, and abrasion resistance of cast steel // Advances in Materials Science and Engineering. 2016, v. 2016, p. 1-8.

12. P. Christodoulou, N. Calos. A step towards designing Fe-Cr-B-C cast alloys // Materials Science and Engineering: A. 2001, v. 301(2), p. 103-117.

13. S. Egashira, T. Sekiya, T. Ueno, M. Fujii. Effect of boron addition on mechanical properties of $\mathrm{Fe}-\mathrm{Ni}$ Mo-B-C sintered alloys // Mechanical Engineering Journal. 2019, v. 6(6), p. 19-00297.

14. H. Tamehiro, M. Murata, R. Habu, M. Nagumo. Optimum microalloying of niobium and boron in HSLA steel for thermomechanical processing // Tetsu-toHagane. 1986, v. 72, p. 458-467.

15. O.V. Sukhova. Influence of mechanisms of structure formation of interfaces in composites on their properties // Metallofizika and Noveishie Technologii. 2009, v. 31(7), p. 1001-1012 (in Russian).

16. O.V. Sukhova, Yu.V. Syrovatko. Features of structurization of composite materials of the solution and diffusion type//Metallofizika $i$ Noveishie Tekhnologii. 2011, v. 33 (Special Issue), p. 371-378 (in Russian).

17. I.M. Spiridonova, E.V. Sukhovaya, S.B. Pilyaeva, O.G. Bezrukavaya. The use of composite coatings during metallurgical equipment parts repair // Metallurgical and Mining Industry. 2002, N 3, p. 58-61.

18. I.M. Spiridonova, O.V. Sukhova, A.P. Vashchenko. Multicomponent diffusion processes in boride-containing composite materials // Metallofizika $i$ Noveishie Tekhnologii. 1999, v. 21(2), p. 122-125 (in Russian).

19. E.V. Sukhovaya. Structural approach to the development of wear-resistant composite materials // Journal of Superhard Materials. 2013, v. 35(5), p. 277283.

20. O. Culha, S. Sahin, I. Ozdemir, M. Toparli. Heat treatment effects on mechanical properties of atmospheric plasma sprayed $\mathrm{Fe}_{\mathrm{x}} \mathrm{B}$ coatings on $\mathrm{Al}$ substrate // Experimental Techniques. 2011, v. 3, p. 43-51.

21. E. Sigolo, J. Soyama, G. Zepon, C.S. Kiminami, W.J. Botta, C. Bolfarini. Wear resistant coatings of boronmodified stainless steels deposited by plasma transferred arc// Surface \& Coatings Technology. 2016, v. 302, p. 255-264.

22. J.C. Farmer, J.J. Haslam, S.D. Day, T. Lian, C.K. Saw, P.D. Hailey, J-S. Choi, R.B. Rebak. Corrosion resistance of thermally sprayed high-boron iron-based amorphous-metal coatings:

$\mathrm{Fe}_{49.7} \mathrm{Cr}_{17.7} \mathrm{Mn}_{1.9} \mathrm{Mo}_{7.4} \mathrm{~W}_{1.6} \mathrm{~B}_{15.2} \mathrm{C}_{3.8} \mathrm{Si}_{2.4} / /$ Journal of Materials Research. 2007, v. 22(8), p. 2297-2311.

23. P.A. Dearnley, T. Bell. Engineering the surface with boron based materials // Surface Engineering. 1985, v. 1(3), p. 203-217.

24. D.J. Sordelet, M.J. Kramer, O. Unal. Effect of starting powders on the control of microstructural development of $\mathrm{Al}-\mathrm{Cu}-\mathrm{Fe}$ quasi-crystalline plasma-sprayed coatings // Journal of Thermal Spray Technology. 1995, v. 4(3), p. 235-244.

25. Yu.A. Yuzvenko, E.I. Frumin, M.A. Pashchenko. Spherical relit. Production method and properties// Powder Metallurgy and Metal Ceramics. 1975, N 7, p. 1-5.

26. I.M. Spiridonova, E.V. Sukhovaya, V.F. Butenko, A.P. Zhudra, A.I. Litvinenko, A.I. Belyi. Structure and properties of boron-bearing iron granules for composites // Powder Metallurgy and Metal Ceramics. 1993, v. 32(2), p. 139-141.

27. K. Niihara, R. Morena, P.H. Hasselman. Evaluation of $\mathrm{K}_{1 \mathrm{C}}$ of brittle solids by the indentation method with low crack-to-indent ratios // Journal of Materials Science Letters. 1982, N 1, p. 13-16.

28. C.J. Smithells. Metals Reference Book. London \& Boston: "Butterworth and Co.", 1976, 446 p.

29. G.V. Samsonov, I.F. Pryadko, L.F. Pryadko. Electron Localization in Solids. M.: "Nauka", 1976, 339 p.

30. G. Li, D. Wang. The self-constituent electronic structure of the interstitial compounds of $\mathrm{Fe}_{2} \mathrm{~B}$ and FeB // Journal of Physics of Condensed Matter. 1989, v. 1, p. $1799-1808$.

Article received 04.03.2020 


\section{СТРУКТУРА И СВОЙСТВА ПОРОШКОВ Fе-В-С, ЛЕГИРОВАННЫХ Сr, V, Mo ИЛИ Nb ДЛЯ ПЛАЗМЕННОГО НАПЫЛЕНИЯ}

\section{E.В. Суховая}

Исследовали влияние легирующих элементов на процессы формирования структуры и свойств порошков для плазменного напыления, изготовленных методом распыления вращающегося стержня. Состав порошков находился в следующем концентрационном диапазоне: $\mathrm{B}(10 \ldots 14$ вес.\%), $\mathrm{C}(0,01 \ldots 0,5$ вес.\%), Ме $(0 \ldots 5,0$ вес.\%), где $\mathrm{Me}-\mathrm{Cr}$, V, Mo или $\mathrm{Nb}$, Fe - остаток. Структуру порошков изучали методами металлографии, рентгеноструктурного анализа, сканирующей электронной микроскопии, рентгеноспектрального микроанализа. Механические свойства порошков измеряли на микротвердомере Виккерса. Также определяли прочность на сжатие, окалиностойкость, температуру плавления. Хром и ванадий полностью растворяются в структурных составляющих $\mathrm{Fe}_{2}(\mathrm{~B}, \mathrm{C})$ и $\mathrm{Fe}(\mathrm{B}, \mathrm{C})$ порошков $\mathrm{Fe}-\mathrm{B}-\mathrm{C}$, замещая железо в кристаллических решетках фаз и формируя твердые растворы замещения. Присутствуя в структуре боридов железа, эти элементы повышают их пластичность и сопротивление окислению, но снижают температуру плавления и твердость порошков. Молибден и ниобий в основном присутствуют в структуре в виде вторичных фаз, таких как $\mathrm{Mo}_{2} \mathrm{~B}, \mathrm{Mo}_{2}(\mathrm{~B}, \mathrm{C})$ или $\mathrm{NbB}_{2}$, выделяющихся по границам кристаллов $\mathrm{Fe}_{2}(\mathrm{~B}, \mathrm{C})$. Как следствие, эти легирующие элементы повышают твердость, сопротивление окислению и температуру плавления порошков.

\section{СТРУКТУРА І ВЛАСТИВОСТІ ПОРОШКІВ Fе-В-С, ЛЕГОВАНИХ Cr, V, Mo АБО Nb ДЛЯ ПЛАЗМОВОГО НАПИЛЕННЯ}

\section{O.В. Сухова}

Досліджували вплив легуючих елементів на процеси формування структури та властивостей порошків для плазмового напилення, виготовлених методом розпилення обертового стрижня. Склад порошків знаходився в наступному концентраційному діапазоні: $\mathrm{B}(10 \ldots 14$ ваг.\%), $\mathrm{C}(0,01 \ldots 0,5$ ваг.\%), $\mathrm{Me}(0 \ldots 5,0$ ваг.\%), де $\mathrm{Me}-\mathrm{Cr}$, V, Mo або $\mathrm{Nb}, \mathrm{Fe}$ - залишок. Структуру порошків вивчали методами металографії, рентгеноструктурного аналізу, сканувальної електронної мікроскопії, рентгеноспектрального мікроаналізу. Механічні властивості порошків вимірювали на мікротвердомірі Віккерса. Також визначали міцність на стиск, окалиностійкість, температуру плавлення. Хром та ванадій повністю розчиняються в структурних складових $\mathrm{Fe}_{2}(\mathrm{~B}, \mathrm{C})$ i $\mathrm{Fe}(\mathrm{B}, \mathrm{C})$ порошків $\mathrm{Fe}-\mathrm{B}-\mathrm{C}$, заміщуючи залізо в кристалічних гратках фаз i формуючи тверді розчини заміщення. Проникаючи в структуру боридів заліза, ці елементи підвищують їх пластичність і опір окисленню, але знижують температуру плавлення і твердість порошків. Молібден та ніобій в основному присутні в структурі у вигляді вторинних фаз, таких як $\mathrm{Mo}_{2} \mathrm{~B}, \mathrm{Mo}_{2}(\mathrm{~B}, \mathrm{C})$ або $\mathrm{NbB}$, що виділяються по межах кристалів $\mathrm{Fe}_{2}(\mathrm{~B}, \mathrm{C})$. Як наслідок, ці легуючі елементи підвищують твердість, опір окисленню і температуру плавлення порошків. 